\title{
PENERAPAN METODE DEMONSTRASI UNTUK MENINGKATKAN KETERAMPILAN SHALAT WAJIB DI KELAS III MI MARAQITTA'LIMAT ANYAR TAHUN PELAJARAN 2017/2018
}

\author{
M. Arzani \\ Dosen STKIP Hamzar \\ Email : zanarzan25@gmail.com
}

Tujuan penelitian ini adalah untuk mengetahui peningkatan keterampilan shalat wajib dengan menerapkan metode demonstrasi di kelas III MI Maraqitta'limat Anyar Desa Anyar Kecamatan Bayan Kabupaten Lombok Utara Tahun Pelajaran 2017/2018.Penelitian ini menggunakan rancangan penelitian tindakan kelas (PTK).Penelitian dilakukan dengan menggunakan 2 siklus yaitu siklus I dan siklus II, Setiap siklus terdiri dari 4 tahap yaitu tahap perencanaan, tindakan, observasi dan refleksi. Penelitian dalam pelaksanaan pembelajaran dilakukan oleh guru dan peneliti hanya sebagai observer. Hasil penelitian menunjukan bahwa hasil belajar praktik shalat zuhur yaitu dari pra tindakan nilai rata-rata siswa 63,60 dan ketuntasan secara klasikal yaitu 40,00\%, siklus I nilai rata-rata siswa 70,13 dan ketuntasan klasikalnya yaitu 73,33\%, siklus II nilai rata-rata siswa 75,80 dan ketuntasan klasikalnya 80,00\% dari hasil ini menunjukan adanya peningkatan mulai dari tahap siklus I dan siklus II.

\section{Kata Kunci: Keterampilan Sholat Wajib, Metode Demonstrasi}

\section{PENDAHULUAN}

Salah satu masalah yang di hadapi dunia pendidikan adalah masalah lemahnya peroses pembelajaran.Peroses pembelajaran anak kurang di dorong untuk mengembangkan kemampuan berpikir.Peroses pembelajaran di dalam kelas di arahkan kepada kemampuan anak untuk menghafal informasi.Otak anak di paksa untuk mengingat dan menimbun berbagai informasi tanpa di tuntut untuk memahami informasi yang diingatnya itu untuk menghubungkannya dengan kehidupan sehari-hari.Tujuan metode demonstrasi ialah tujuan pengajaran menggunakan untukmemperlihatkan proses terjadinya suatu peristiwa sesuai materi ajar. Cara pencapainnya dan kemudahan untuk di pahami oleh siswa dalam pengajaran di dalam kelas.Kesungguhan dalam peroses pembelajaran di harapkan dapat meningkatkan keterampilan belajar siswa, karena di dalam pembelajaran shalat terdapat rukun-rukun shalat seperti ruku dan sujud.Media dan metode harus sesuai dengan pembelajaran, jika tidak sesuai dengan pembelajaran dapat menyebabkan siswa merasa jenuh, bosan, sehingga hal inilah yang akan mempengaruhi kegiatan belajar mengajar. Penanaman nilai agama sejak dini merupakan syarat mutlak untuk mencapai nilai sikap dan norma agama untuk membangun dunia pendidikan bangsa yang berkarakter, dan untuk membangun keharmonisan dalam menjalani kehidupan dunia dan akhirat. Nilai-nilai tersebut dapat dijadikan pondasi agar mereka tidak keluar dari ajaran-ajaran agama. Pada prinsipnya pelajaran agama islam membekali siswa agar memiliki pengetahuan lengkap tentang hukum islam dan mampu mengaplikasikannya dalam bentuk ibadah kepada Allah SWT. Siswa dapat melaksanakan kewajiban sebagai hamba Allah SWT yaitu beribadah yang benar menurut agama islam sesuai dengan yang diajarkan dan diperaktikan oleh Rasulullah SAW. Shalat adalah tiang agama, barang siapa yang mendirikan shalat berarti dia menegakkan agama dan barang siapa meninggalkan shalat, berarti meruntuhkan agama. Upaya pengefektipan tidak terlepas dari penggunaan metode yang tepat, adapun target peneliti untuk meningkatkan keterampilan shalat wajib yaitu dengan menggunakan metode demonstrasi.

\section{KAJIAN PUSTAKA \\ Keterampilan Shalat Wajib}

Menurut Kamus Besar Bahasa Indonesia dalam skripsi Nur'aini (2014:9) bahwa keterampilan berasal dari kata terampil 
artinya cekatan, cakap mengerjakan sesuatu, dan menempatkan sesuatu sesuai pada porsinya dengan tepat dan akurat, sehingga segala yang di kerjakan dapat terselesaikan dengan baik dan benar.

\section{Macam Shalat Wajib/Fardu dan Waktunya}

Adapun macam-macam shalat fardhu dan waktunya adalah sebagai berikut:

a) Shalat Dzuhur dilakukan sebanyak 4 rakaat. Waktu yang di perbolehkan adalah ketika matahari mulai condong kearah barat sampai bayangan suatu benda menjadi sama panjangnya dengan benda aslinya. Kira-kira pukul 12:17 sampai dengan 15:36 menit.

b) Shalat Ashar dilakukan sebanyak empat rakaat.Waktu yang diperbolehkan adalah mulai sejak habis waktu shalat dzuhur sampai terbenamnya matahari di ufuk barat.Kira-kira pukul 15:36 sampai dengan 18:16 menit.

c) Shalat Magrib dilakukan sebanyak 3 rakaat. Waktu yang di perbolehkan adalah mulai terbenamnya matahri sampai hilang cahaya di ufuk barat. Kira-kira pukul 18:16 sampai dengan 19:25 menit.

d) Shalat Isya dilakukan sebanyak 4 rakaat.Waktu yang di perolehkan adalah saat habis waktu magrib sampai terbit fajar.Kira-kira pukul 19:25 sampai dengan 04:30 menit.

e) Shalat Shubuh dilakukan sebanyak 2 rakaat.Waktu yang di perbolehkan adalah semenjak terbit fajar (fajar siddiq) hingga terbit matahari. Kira-kira pukul 04:30sampai dengan 05.30 pagi (Abdillah, 2006:45).

\section{Hakekat Keterampilan Shalat}

Hakekat keterampilan shalat adalah kemampuan untuk melaksanakan atau mengerjakan semua hal yang berkaitan dengan pelaksanaan shalat mulai dari syarat sah shalat, rukun shalat, sunnah shalat dan hal yang membatalkan shalat.

b. Metode Demonstrasi

1. Pengertian metode demonstrasi

Metode adalah cara yang digunakan untuk mengimplementasikan rencana yang sudah di susun dalam kegiatan nyata agar tujuan yang telah di susun tercapai secara optimal (Sanjaya, 2006:147). Metode ini di gunakan untuk merealisasikan strategi yang telah di tetapkan, dengan demikian metode demonstrasi sangat penting di terapkan dalam meningkatkan keterampilan shalat wajib.

\section{Manfaat Metode Demonstrasi}

Menurut Muhibbin dalam skripsi Nurae'ni (2014:24) manfaat metode demonstrasi adalah:

a) Perhatian siswa dapat lebih di pusatkan

b) Peroses belajar siswa lebih terarah pada materi yang sedang di pelajari.

c) Pengalaman dan kesan sebagai hasil pembelajaran lebih melekat dalam diri siswa.

\section{Kelebihan Metode Demonstrasi}

Menurut Surakhmad (1994 : 111-112) kelebihan metode demonstrasi yaitu perhatian siswa dapat diarahkan pada hal-hal yang dianggap penting sehingga hal-hal yang penting ini dapat diamati seperlunya. Perhatian siswa lebih mudah dipusatkan pada proses belajar dan tidak tertuju pada hal-hal yang tidak relevan.Mengurangi kesalahan-kesalahan bila dibandingkan dengan kegiatan hanya mendengar ceramah atau membaca di dalam buku, karena siswa memperoleh gambaran yang jelas dari hasil pengamatannya.Siswa turut aktif berdemonstrasi, maka ia akan memperoleh pengalaman-pengalaman praktek untuk mengembangkan kecakapannya dan memperoleh pengakuan dan pengharapan dari lingkungan sosialnya. Masalah yang menimbulkan pertanyaan pada siswa dapat dijawab lebih teliti waktu proses demonstrasi.

\section{Kekurangan Metode Demonstrasi}

Menurut Surakhmad (1994 : 111-112) kekurangan metode demonstrasi yaitu tidak cukupnya alat-alat mengakibatkan tidak setiap siswa mendapat kesempatan untuk mengadakan demonstrasi.Memerlukan jangka waktu yang lama, maka ia harus menanti untuk dapat melanjutkan pelajaran.Kurangnya persiapan dan pengalaman siswa akan menimbulkan kesulitan didalam melakukan demonstrasi.

\section{Langkah-Langkah Menggunakan Metode Demonstrasi}

Menurut Sanjaya, (2006:153-154) ada beberapa langkah- langkah menggunakan metode demonstrasi di antarnya:

Tahap Persiapan

1. Rumusan tujuan yang harus dicapai oleh siswa setelah proses demonstrasi berakhir. 
2. Persiapkan garis besar langkah-langkah demonstrasi yang akan dilakukan. Garisgaris besar demonstrasi diperlakukan sebagai panduan untuk menghindari kegagalan.

3. Lakukan uji coba demonstrasi. Uji coba meliputi segala peralatan yang diperlukan

Tahap Pelaksanaan

Langkah Pembukaan

1. Sebelum demonstrasi dilakukan ada bebarapa hal yang harus diperhatikan.

2. Langkah Pelaksanaan Demonstrasi.

3. Langkah Mengakhiri Demonstrasi.

Apabila demonstrasi selesai dilakukan, proses pembelajaran perlu diakhiri dengan memberikan tugas-tugas tertentu yang ada kaitannya dengan pelaksanaan demonstrasi dan proses pencapaian tujuan pembelajaran.

\section{Kerangka Berpikir}

Shalat wajib merupakan salah satu kewajiban bagi tiap muslim untuk melaksanakannya, bagi yang sudah memenuhi syarat-syaratnya, sehingga Shalat harus di ajarkan pada anak-anak didik mulai sejak dini. Penggunaan metode ceramah secara dominan yang diterapkan oleh guru pada proses pembelajaran shalat. Hal ini mengakibatkan proses pembelajaran tidak dapat berjalan secara maksimal sesuai dengan tuntutan pembelajaran shalat wajib yang baik dan benar.

\section{Hipotesis Tindakan}

Berdasarkan uraian tersebut, hipotesis tindakan dalam penelitian ini adalah Metode Demonstrasi dapat Meningkatkan Keterampilan Shalat wajib di MI Maraqitta'limat Anyar Desa Anyar Kecamatan Bayan Kabupaten Lombok Utara Tahun Pelajaran 2017-2018.

\section{METODE PENELITIAN}

Rancangan penelitian sangat ditentukan oleh tujuan penelitian itu sendiri. Menurut Nasution (2002:23) memberikan definisi bahwa rancangan penelitian adalah perencanaan tentang cara mengumpulkan dan menganalisa data agar dapat melaksanakan secara ekonomis serta serasi dengan tujuan penelitian itu. Suatu penelitian dapat diukur secara langsung dengan nilai atau angka maka penelitian tersebut dinamakan penelitian kuantitatif, sedangkan penelitian yang tidak diukur dengan nilai atau angka dinamakan penelitian kualitatif.

Penelitian

dilaksanakan dalam waktu 2 (Dua) bulan yang di laksanakan mulai bulan 29 September sampai dengan 28 Nopember 2017 di MI Maraqitt'alimat Anyar Tahun Pelajaran 2017, di MI Maraqitt'alimat Anyar Dusun Pelabasari, Desa Anyar, Kecamatan Bayan, Kabupaten Lombok Utara Tahun Pelajaran 2017-2018.

\section{Subyek Penelitian}

Adapun sasaran penelitian ialah seluruh siswa kelas 3 dengan jumlah siswa (15) yang terdiri dari (8) laki-laki dan (7) perempuan di MI Maraqitt'limat Anyar, Kecamatan Bayan Kabupatan Lombok Utara Tahun Pelajaran 2017-2018

\section{Sumber Data}

Menurut Arikunto (2013:172) sumber data adalah subjek dari mana sesuatu data dapat di peroleh.Menurut Sutopo (2006:56-57) sumber data adalah tempat data di peroleh, dengan menggunakan metode tertentu baik berupa manusia, artefak ataupun dokumen.Sedangkan Menurut Moleong (2001:112) pencatatan sumber data melalui wawancara dan pengamatan merupakan hasil gabungan dari kegiatan melihat, mendengar, dan bertanya.Data yang diperlukan dalam penelitian ini ada 2 macam, yaitu data primer dan data sekunder.

\section{Tehnik dan Alat Pengumpulan Data}

Tehnik pengumpulan data adalah cara yang digunakan untuk memperoleh data yang dibutuhkan (Arikunto, 2010:175). Adapun tehnik dalam pengumpulan data dalam penelitian tindakan kelas ini meliputi: Observasi, Tes praktik, Wawancara, Dokumentasi

\section{Validasi Data}

Peneliti

menggunakan tehnik triangulasi yaitu tehnik pemeriksaan ke absahan data yang memanfaatkan sesuatu yang lain di luar data itu untuk keperluan pengecekan atau pembanding terhadap suatu data (Iskandar, 2009:84). Peroses dalam membuat kesimpulan tentang penerapan keterampilan shalat wajib melalui metode demonstrasi bisa dilakukan secara tepat dan di terima ke absahannya. Adapun teknik-teknik 
validitas yang di lakukan peneliti yaitu: Triagulasi teknik, Triangulasi sumber data.

\section{Analisis Data}

Kegiatan penelitian dilaksanakan secara sistematis, yaitu penelitian dilakukan tahap demi tahap untuk mengetahui tingkat kemampuan siswa setelah perbaikan dilakukan. Adapun kegiatan yang dilakukan yaitu dengan dua carayaitu; Analisi kuantitatif yang di gunakan unuk menganalisi aktivitas belajar siswa selama pembelajaran berlangsung yaitu:

Rumus penilaian di hitung dengan precentages correction (Wardani: 2008)

\section{Indikator Kinerja}

Kriteria keberhasilan siswa dalam mempelajari penerapan keterampilan shalat wajib dengan metode demonstrasi di kelas III MI Maraqitta'limat Anyar Kecamatan Bayan adalah siswa dikatakan lulus jika secara indivdual mendapat nilai di atas KKM yaitu $\geq$ 65 dan dikatakan tuntas secara klasikal apabila mendapat nilai $\geq 70 \%$ Keaktifan siswa dikatakan tuntas jika nilai $\geq 2.0$ dan masuk dalam kategori cukup.

\section{Prosedur Penelitian}

Penelitian tindakan kelas yang digunakan dalam penelitian ini adalah menggunakan model Kemmis dan Mc.Taggart (Arikunto, 2010:137). Adapun model penelitian tindakan kelas yang dimaksud adalah menggambarkan adanya 4 (empat) langkah yang meliputi perencanaan (planning), tindakan (acting), pengamatan (observating), dan refleksi (reflecting).

\section{Siklus I}

\section{Perencanaan}

Tahap Perencanaan menjelaskan apa, mengapa, kapan, dimana, oleh siapa, dan bagaimana tindakan tersebut dilakukan. Tahap perencanaan di lakukan sebagai upaya memecahkan persoalan yang di hadapi pembelajaran pada tahap pra tindakan.Berdasarkan refleksi tindakan awal itulah digunakan sebagai perencanaan perbaikan pembelajaran. Kegiatan yang di lakukan dalam tahap ini adalah penyusunan perangkat pembelajaran, meliputi Rencana Pelaksanaan Pembelajaran (RPP), mempersiapkan sarana pendukung pembelajaran, instrument penelitian dan mempersiapkan cara menganalisis data pengaturan ruang kelas yang rapi dan teratur, menyiapkan media yang di gunakan, serta lembar observasi pelaksanaan RPP.

\section{Pelaksanaan}

Pelaksanaan yaitu implementasi atau penerapan isi rancangan di dalam kancah, yaitu mengenakan tindakan dalam kelas. Kegiatan yang di lakukan pada pada tahap ini sebagai berikut:

Guru membuka pembelajaran dengan berdoa yang di pimpin oleh ketua kelas.

Guru memberikan penjelasan tentang shalat secara umum dan menjelaskan lebih detail tentang gerakan dan bacaan shalat wajib baik secara lisan maupun mendemonstrasikan di depan siswa.

Menempelkan gambar orang shalat di depan kelas untuk di cermati dan di ingat karena guru hanya mempraktikan beberapa menit saja.

Sebelum Melakukan penilaian terhadap anak, anak di berikan kesempatan untuk mendemonstrasikan gerakan dan bacaan.memberikan kesempatan kepada siswa yang belum mengerti tentang tata cara shalat untuk bertanya.

Setiap Siswa mendemonstrasikan gerakan dan bacaan shalat di depan kelas sesuai tata cara shalat yang sudah di ajarkan dan dilaksanakan secara individu. Siswa yang belum mendapatkan giliran maupun yang sudah melakasnakan demonstrasi shalat wajib memperhatikan temannya yang sedang mendemonstrasikan shalat. Guru memberikan kesimpulan dan nilai terhadap hasil demonstrasi shalat wajib.

\section{Pengamatan}

Pengamatan dilakukan selama pelaksanaan tindakan berlangsung dari awal sampai akhir, observasi bertujuan untuk mengetahui kekurangan dan kelebihan yang terjadi selama pelaksanaan tindakan. Kekurangan dan kelebihan kemudian dijadikan pedoman pada tindakan berikutnya, agar tidak terjadi kesalahan yang sama.

Selama peroses observasi guru mengamati secara langsung tentang : (1). Kesiapan materi dan mental peserta didik 
dalam mengawali pembelajaran shalat wajib, (2). Respon peserta didik dalam proses belajar mengajar, (3). Pembuatan instrumen penelitian, (4). Pengumpulan data dari tes praktik untuk mengetahui bacaan dan gerakan dalam mendemonstrasikan shalat dan dokumen foto digunakan untuk memperkuat data yang telah di lakukan sebagai bukti.

\section{Refleksi}

Refleksi yaitu kegiatan untuk mengemukakan kembali apa yang sudah terjadi. Kegiatan refleksi di lakukan setelah pelaksanaan tindakan dan pengamatan sebelumnya. Refleksi ini di lakukan untuk mengevaluasi kelemahan dan kelebihan dari tindakan pembelajaran yang telah di lakukan. hasil tindakan serta

hambatan-hambatan yang di hadapinya dan selalu berdiskusi dengan teman sejawat sesama pengajar untuk mendapatkan masukan yang bermanfaat. Hasil refleksi ini berguna untuk menentukan tingkat keberhasilan dari tindakan yang telah di lakukan dan sebagai dasar pertimbangan untuk menyusun rencana kegiatan selanjutnya

\section{HASIL PENELITIAN}

Penelitian tindakan kelas ini dilaksanakan pada siswa kelas III MI Maraqitta'limat Anyar Kecamatan Bayan yang dilakukan selama dua bulan dari tanggal 29 September s/d 28 Nopember 2017. Penelitian ini terdiri dari dua siklus yang meliputi siklus I dan siklus II, dimana setiap siklus dalam penelitian ini terdiri dari empat tahap antara lain: (1) Perencanaan, (2) Pelaksanaan tindakan, (3) Pengamatan atau observasi, (4) Refleksi.

Sebelum melaksanakan tindakan penelitian pada tahap siklus I dan II, terlebih dahulu di adakan tindakan awal berupa pemberian tes praktik shalat pratindakan yang bertujuan sebagai tolak ukur pelaksanaan kegiatan selanjutnya yang di ikuti oleh 15 siswa yang terdiri dari 8 Laki-Laki dan 7 Perempuan, dari 15 siswa yang mengikuti kegiatan tersebut nilai rata-rata nya yaitu 63,6. Terdapat 6 siswa yang tuntas atau sebanyak 40,00\% dan 9 siswa yang tidak tuntas atau sebanyak $60,00 \%$ dan termasuk dalam kategori baik yaitu 5 siswa $(33,33 \%), \quad 6$ siswa $(40,00 \%)$, yang mendapatkan kategori cukup, yang termasuk dalam kategori kurang yaitu 4 siswa $(26,67 \%)$.

\section{Siklus I}

Hasil pengamatan aktivitas siswa pada saat peroses mendemonstrasikan shalat wajib zuhur.Perolehan jumlah skor secara menyeluruh yaitu 42 dengan skor maksimal (tertinggi) $=$ jumlah pernyataan $(15) \mathrm{x}$ jumlah skor $(4)=60$ dengan menggunakan skala 4 (jumlah skor) maka obeservasi aktivitas siswa kelas 3 secara umum yaitu $42 / 60 \times 4=2,8$ dengan presentase $70,00 \%$ data menunjukan nilai rata-rata aktivitas siswa yaitu 2,8 dengan kualifikasi baik dan presentasenya $70 \%$, hal ini menunjukan adanya peningkatan aktivitas siswa dari sebelumnya.

\section{Siklus II}

Hasil pengamatan aktivitas siswa pada tahap siklus II saat peroses pembelajaran berlangsung.Perolehan jumlah skor secara menyeluruh yaitu 48 dengan skor maksimal (tertinggi) $=$ jumlah pernyataan (15) $\mathrm{x}$ jumlah skor $(4)=60$ dengan menggunakan skala 4 (jumlah skor) maka obeservasi aktivitas siswa kelas 3 secara umum yaitu 48/60 x $4=3,2$ sehingga data menunjukan nilai rata-rata aktivitas siswa yaitu 3,2 dengan kualifikasi baik dan presentasenya $80 \%$, hal ini menunjukan adanya peningkatan aktivitas siswa dari siklus I ke siklus II.

\section{PEMBAHASAN}

Penelitian yang dilakukan adalah penilitian tindakan kelas (PTK) yaitu mendemonstrasikan shalat wajib zuhur. Sebelum tahap siklus dilkasanakan terlebih dahulu diadakan pratindakan sehingga pada penelitian ini ada 3 tahap, dan tahap ini saling berkaitan satu dengan yang lain. Ada pra tindakan, siklus I dan siklus II, terdiri dari perencanaan, tindakan, observasi dan refleksi, dari pratindakan ini kita bisa mengetahui kemampuan siswa dari tes praktik shalat zuhur dan dari hasil pratindakan kita bisa merencanakan langkah-langkah pembelajaran yang lebih bagus pada tahap selanjutnya yaitu pada tahap siklus I dan II.

Adapun penjelasan pada tahap pratindakan, siklus I dan siklus II yaitu sebagi berikut:

\section{Kondisi Awal}


Pada kondisi awal ketererampilan shalat siswa kelas III MI Maraqita'limat Desa Anyar Kecamatan Bayan. Nilai rata-rata termasuk dalam kategori cukup yaitu 63,6, dari 15 siswa terdapat 6 siswa $(40,00 \%)$ yang tuntas karena mereka memperhatikan apa yang dijelaskan oleh guru. Terdapat 9 siswa $(60,00 \%)$ yang tidak tuntas karena mereka sibuk sendiri, ngobrol dengan temannya, dan tidak fokus memperhatikan apa yang di jelaskan oleh guru. Siswa yang mendapatkan kategori sangat baik belum ada atau 0\%. Termasuk dalam kategori baik yaitu 5 siswa $(33,33 \%)$, 6 siswa $(40,00 \%)$ yang mendapatkan kategori cukup, yang termasuk dalam kategori kurang yaitu 4 siswa $(26,67 \%)$.

\section{siklus I}

Pada siklus I telah menunjukan adanya peningkatan hasil belajar dan termasuk dalam kategori baik yaitu memperoleh nilai rata-rata 70,13 yang sebelumnya hanya $(63,6)$ hasil pada pra tindakan, dari 15 siswa terdapat 11 siswa yang tuntas sehingga ketuntasan klasikalnya yaitu $73,33 \%$. Siswa yang tuntas lebih memperhatikan apa yang di ajarkan oleh guru, menuruti perintah guru, dan tidak mainmain saat proses pembelajaran berlangsung, dan terdapat 4 siswa yang tidak tuntas yaitu $26,67 \%$. Siswa yang tidak tuntas di sebabkan karena siswa kurang memperhatikan apa yang di jelaskan oleh guru, lebih cendrung bermain dengan teman sebangkunya dan berbicara saat guru menjelaskan. Terdapat 10 siswa yang mendapatkan kategori baik yaitu sebanyak $66,67 \%$, termasuk kedalam kategori cukup yaitu 4 siswa atau sebanyak $26,67 \%$, dan I Siswa $(6,66 \%)$ yang termasuk dalam kategori kurang dan yang termasuk kedalam sangat baik dan sangat kurang yaitu tidak ada $0 \%$.

\section{Siklus II}

Pada Siklus II telah menunjukan adanya peningkatan hasil belajar dalam kategori baik yaitu memperoleh nilai rata-rata 75,80 yang sebelumnya nilai rata-rata kelas pada siklus I 70,13, dari 15 siswa terdapat 12 siswa $(80,00 \%)$ yang tuntas karena mereka mulai lebih fokus memperhatikan apa yang di jelaskan oleh guru, mengikuti peraturan dan tidak main-main saat proses pembelajaran berlangsung. terdapat 3 siswa $(20,00 \%)$ yang tindak tuntas karena mereka masih bermain- bermain, berbicara dengan teman sebangkunya, dan tidak fokus memperhatikan yang di jelaskan oleh guru walupun guru sudah memperingati mereka. terdapat I siswa 6,67\% mendapatkan kategori sangat baik, 11 siswa atau sebanyak $73,33 \%$ mendapatkan kategori baik, 3 siswa (20\%) termasuk dalam kategori cukup dan tidak ada siswa yang termasuk dalam kategori kurang dan sangat kurang atau sebanyak $0 \%$

Berdasarkan penelitian menunjukan bahwa melalui metode demonstrasi yang di terapkan pada shalat wajib dapat meningkatkan keterampilan shalat dengan bantuan media gambar dan di sertai dengan penjelasan lisan yang di lakukan oleh guru.Hal ini juga sesuai dengan pendapat penelitian yang di lakukan oleh Nurae'ni (2014:60) Hasil penelitian menunjukan bahwa pembelajaran melelui metode demonstrasi dapat meningkatkan keterampilan ibadah shalat dan dapat mengembangkan kemampuan praktek shalat.

Hal ini sejalan dengan pendapat penelitian dalam skripsi Nurhuda (2016:79) bahwa dengan menerapkan metode demonstrasi pembelajaran akan lebih aktif, lebih semangat, akhirnya pun bisa lebih meningkat praktik shalat, sesuai peneliti harapkan. Hal ini juga sesuai dengan pendapat Ristiana (2014:73) bahwa metode demonstrasi dapat meningkatkan keterampilan shalat pada mata pelajaran fiqih, dan pendapat Supayo (2009:69) dengan menerapkan metode demonstrasi dapat meningkatkan minat dan belajar siswa dalam shalat.

Berdasarkan pendapat di atas, peneliti menyimpulkan bahwa keterampilan shalat wajib dengan mendemonstrasikan shalat zuhur dapat di tingkatkan melalui metode demonstrasi, selain itu metode demonstrasi akan lebih efektip jika dibandingkan dengan metode ceramah.

\section{KESIMPULAN}

Berdasarkan hasil pelaksanaan penelitian tindakan kelas di kelas III MI Maraqitt'limat Anyar Desa Anyar Kecamatan Bayan Kabupaten Lombok Utara Tahun Pelajaran 2017-2018 dapat di simpulkan :

Pelaksanaan peroes pembelajaran keterampilan shalat melalui metode demonstrasi siswa kelas III MI Maraqitt'alimat 
Anyar Kecamatan Bayan Kabupaten Lombok Utara berdasarkan rencana pembelajaran yang telah di susun dan di buat, dapat meningkatkan keterampilan siswa dalam melaksanakan shalat wajib.

Metode demonstrasi dapat meningkatkan keterampilan shalat wajib siswa. Terbukti dari nilai rata-rata pada penilaian tahap pra tindakan yaitu 63,6 dengan ketuntasan klasikalnya yaitu 40,00\%. Pada siklus I nilai rata-rata siswa meningkat menjadi 70,13 dengan ketuntasan klasikal $73,33 \%$ atau mengalami peningkatan sebesar $33.33 \%$ dari tahap pra tindakan ke tahap siklus I. dan pada siklus II nilai keterampilan shalat siswa meningkat menjadi 75,80 dengan ketuntasan klasikalnya 80,00\%, dengan demikian mengalami peningkatan sebesar 6,67\% dari siklus I ke siklus II.

Model pembelajaran dengan menggunakan metode demonstrasi efektif di gunakan dalam pembelajaran keterampilan shalat kelas III MI Maraqitt'alimat Anyar Kecamatan Bayan Kabupaten Lombok Utara.

\section{DAFTAR PUSTAKA}

Abdillah, Ibnu Ahyar. 2006. Tuntunan Ibadah Shalat Lengkap Disertai Zizkir dan Doa. Surabaya : Kashiko Surabaya.

Arikunto, S.. 2013. Prosedur Penelitian Suatu Pendekatan Praktek. Jakarta : Rineka Cipta. 1999.Dasar-Dasar Evaluasi Pendidikan.Jakarta : Bumi Aksara. . 2010. Prosedur Penelitian Suatu Pendekatan Praktek. Jakarta : Rineka Cipta.

Akbar, Sa'dun. 2013. Instrumen Perangkat Pembelajaran. Bandung : PT Remaja Rosda Karya.

Djamarah, B. S. dan Zaini, A. 2010. Strategi Belajar Mengajar. Jakarta : Rineka Cipta.

Erwan, P. A. dan Sulistyastuti, R. D. 2007.Metode Penelitian Kuantitatif Untuk Administrasi Publik Dan Masalah Sosial.Yogyakarta : Cahaya Media.

Fathul M., 2013. Pintar Agama Islam. Banjarnegara: Bara Media

Fuad, Jauhar dan Hamam. 2012. Teori dan Praktik Penelitian Tindakan Kelas
(PTK). Tulungagung : $\quad$ Stain Tulungagung.

Hadi, Sutrisno. 2004. Metodologi Research. Yogyakarta : Yayasan Penerbitan Fakultas Psikologi Universitas Gadjah Mada.

Hamruni, 2012.Strategi dan Model-model Pembelajaran

Aktif,

Menyenangkan. Yogyakarta : Investidaya

Hakim, Lukman.2013. Bimbingan Shalat dan Doa Pilihan Disertai Juz Amma Untuk Anak-Anak.Yogyakarta : Media Pustaka

Irsyad, Muhammad, 2012. Risalah Tuntunan Shalat Lengkap. Magelang : Cahaya Putra.

Moleong, J. 2012. Metodologi Penelitian Kualitatif. Bandung : Rosda.

Kemenag RI. 2012. Alqur'an dan Terjemahannya. Surabaya : PT. Sinergi Pustaka Indonesia.

Munfadhil, S. 2009. Peningkatan Keterampilan Shalat dengan Menggunakan Metode Drill Siswa Kelas III MI Muhamadiyah Kec. Wonosegoro Kab. Boyolali Tahun Pelajaran 2009/2010. [Online]. Tersedia: http://www.google.co.id/search?ptk+mu nfadhil+keterampilan+shalat+metode $+\mathrm{dr}$ ill.pdf. [Di unduh 28 Juli 2017].

Nasution, S. 2002. Berbagai Pendekatan Dalam Peroses Belajar Mengajar. Bandung : PT. Bumi Aksara.

Nurhuda, Zaidun. 2016. Penerapan Metode Demonstrasi Untuk Meningkatkan Hasil Belajar Siswa Pada Mata Pelajaran Fiqih Materi Shalat Id Kelas IV MI Baran Kecamatan Semarang Tahun Pelajaran 2015/2016.[Online].Tersedia http//library. walisongo.ac.id /digilib/files/disk1/128/jtptain -gdlmuhaiminur-6371-1-fileskr-n.pdf. [Di unduh Selasa Tanggal 12 Desember 2017, 10:48 WITA).

Narwati, Sri. 2011. Creative Learning. Yogyakarta : Famili.

Nuraeni, N. 2014.Upaya Meningkatkan Keterampilan Shalat Melalui Metode Demonstrasi di SDN Cipicung 05 Kecamatan Cileungsi Kabupaten Bogor Tahun Pelajaran 2014.[Online].Tersedia :http://www.repositery.uinjkt.ac.id/dspac 
e/bitstream/123456789/28613/1/N.\%20

NURAENI-FITK.pdf. [Di unduh 27 Juli 2017].

Poerwadarminta, 1984.Kamus Bahasa Indonesia.Jakarta : Balai Pustaka

Purwanto.2008. Metodologi Penelitian Kuantitatip Untuk Psikologi dan Pendidikan.Jakarta : Pustaka Belajar.

Rahadi, Aristo. 2003. Media Pembelajaran. Jakarta : Depdikbud.

Rosyid, Muhammad, 2007. Indeks Al-Qurean A-Z.Yogyakarta : Diglossia.

Surakhmad, Winarno. 1994. Pengantar Interaksi Mengajar Belajar. Bandung : Tarsito.

Ristina.2014. Upaya Meningkatkan Keterampilan Shalat Melalui Metode Demonstrasi Pada Mata Pelajaran Fiqih Siswa Kelas II Negeri 2 Sucenjurutengah Tahun 2013/2014.[Online].Tersedia Pelajaran http:/digilib.uinsuka.ac.id/14209/2/BAB 520IV\%2C\%20DAFTAR\%20PUSTAK A.pdf. [Di unduh Selasa Tanggal 12 Desember 2017, 10:48 WITA).

Syah, Muhibbin. 2008. Psikologi Pendidikan. Bandung : Remaja Rosdakarya

Sanjaya, Wina. 2006. Strategi Pembelajaran. Jakarta : Kencana.

Sudjana, Nana. 2009. Dasar-dasar Proses Belajar Mengajar. Bandung : Sinar Baru Algensindo.

Supayo.2009. Upaya Meningkatkan Minat Belajar Mata Pelajaran Pendidikan Agama Islam Melalui Penerapan Metode Demonstrasi Pada Siswa Kelas IV SD Negeri 2 Soborejo Kecamatan Pringsurat Kabupaten Temanggung Tahun Ajaran 2009/2010.[Online].Tersedia (hhtp:/perpus.iainsalatiga.ac.id/docfiles/f ulltext/9d023e8b95d64408.pdf.[Di unduh Selasa Tanggal 28 Juli 2017, 10:48 WITA).

Tamrin, Mohammad Husni. 2009. Meningkatkan Peraktik Shalat Melalui Metode Demonstrasi Pada Siswa Kelas IV Sekolah Dasar Negeri Barambai Kolam Kiri IV Barito Kuala Tahun Pelajaran 2009.[Online].Tersedia :http://idr.iain-antasari.ac.id/id/e print 1654.pdf [Di unduh 28 Juli 2017. 11:00 WITA].

Wadji, Firdaus dan Saira, R. 2009.Buku Pintar Shalat Wajib dan Sunnah.Jakarta : PT. Ikrar Mandiriabdi.

Widyoko, Eko Putro. 2014. Penilaian Hasil Pembelajaran di Sekolah. Yogyakarta : Pustaka Pelajar.

Yuwono, dkk. 2005. Bahasa dan Sastra Indonesia. Surakarta : Teguh Karya. 